\title{
Efficiency and Equity In Interregional Environmental Management ${ }^{\dagger}$
}

\author{
John H. Cumberland*
}

\section{INTRODUCTION}

In addressing environmental issues, the comparative advantage of economists has led them to emphasize efficiency issues, which yield more readily to economic calculus than do equity issues, which fall among the thickets of interpersonal comparisons and value systems. The difficulty of sorting out equity and efficiency issues is compounded in a hierarchical, pluralistic structure like that of the U.S. with conflicting lines of authority at the federal, state, metropolitan, and local levels. Consequently, we have not developed a coherent national policy on certain critical problems, such as the siting of hazardous facilities and the establishment of property rights in environmental resources.

Failure to solve the problems of siting hazardous facilities, such as nuclear plants and toxic waste repositories, has become even more serious as we move into an era of growing emphasis upon military build-up and energy self-sufficiency, both of which will require construction of facilities and storage of waste. The estimated multi-billion dollar cost of financing a superfund to clean up the sites of previously discharged toxic wastes is partial evidence of the high cost of delayed planning.

The goals of the new administration to reduce federal regulation, return environmental administration to the states and place heavy reliance upon market decisions offer additional reason for re-examining decision making processes and procedures at this time.

The challenge is to find acceptable procedures which permit the achievement of overriding national objectives, such as in the areas of military and energy policy, without either violating the rights of local jurisdictions or giving local areas a veto power which could defeat national goals. Essentially then, the problem is one of identifying opportunities for Pareto improvements. In examining these objectives, this paper will concentrate on the examples of siting hazardous facilities and of marketing emission permits.

\footnotetext{
†Presidential Address, Southern Regional Science Association Meetings, Washington, D.C., April 16, 1981. The author is grateful to Professor Wallace E. Oates, who generously offered advice and comments on an earlier draft of the paper, but who bears no responsibility for remaining shortcomings.
}

*University of Maryland. 


\section{THE SITING OF HAZARDOUS FACILITIES}

Although this section deals primarily with the storage of toxic. substances such as nuclear waste, it will also have applicability to the siting of any other facility which generates detrimental spatial externalities. A specific example is the storage of radioactive waste as proposed in the Waste Isolation Pilot Plant (WIPP) of the Department of Energy. The public hearings which were held on these proposals in 1979 were accompanied by high levels of controversy, including intense opposition of many groups in New Mexico near the proposed location, and equally intense support for the idea not only from the nuclear industries and the Federal Government but also by some state level governmental agencies and local level business groups. ${ }^{1}$

One of the most important issues was the demand of the state government, although in many ways supportive of the WIPP proposal, to have the right of concurrence and consent in siting and other aspects of the project. Significantly, this right of concurrence was never fully resolved, with the Federal Government being reluctant to give up any of its sovereignty and the state government necessarily defending its Constitutional rights. Consequently, the issue was blurred and compromised with vague language.

Another issue which was blurred and confused was the extent to which the project would receive waste from weapons production as contrasted to waste from commercial nuclear power generation facilities. The failure to separate these two sources of waste naturally attracted those opposed in principle to nuclear energy as opponents to the project. There was less controversy about the necessity for storing military nuclear waste.

Opposition to storage of any nuclear waste was voiced at the hearings not only by those whose technical understanding of the hazards of nuclear radiation was very limited, but also by many who had a very sophisticated knowledge of the effect of radiation on the human organism. This opposition came both from those living in the immediate vicinity of the storage project, near Carlsbad, and from many whose homes were located along the rail and highway transportation routes over which thousands of railroad carloads and truckloads of nuclear waste would be transported annually.

Unfortunately, the decision process was presented in terms of a binary goor no-go outcome for the project, with the decision to be made at the level of the Department of Energy or, ultimately, because of its controversial nature, by the Office of the President. In order to minimize controversies and civilian participation, the decision was ultimately made by DOE to proceed with the project, but only for primarily military waste. Meanwhile, nuclear waste from energy production accumulates in local areas where the facilities are inadequate, limited, and potentially hazardous because of hydrological and seismic conditions.

The present procedure of arbitrary site location by the Federal Government is unsatisfactory on a number of grounds. It creates large-scale detrimental externalities and misallocation of resources because the producers of the wastes 
involved have not taken into account the full social cost of creating these wastes and because the detrimental impacts will be arbitrarily imposed in an inequitable fashion on a selected number of receptors or victims. Both the efficiency and equity aspects of this procedure are unsatisfactory and need to be corrected.

The present procedure for federal siting of energy facilities and toxic storage facilities could be characterized as a command and control process. Obviously it does have some potential advantages or it would not continue to exist. It has the attraction of suggesting an apparently low direct cost to the government and taxpayers (although the non-market and indirect costs may be very high). A major potential advantage of this system, when it works well, is that presumably the central government optimizes for the entire nation when it selects a site for a facility with widespread detrimental externalities. If the political process has worked well, then the adverse impacts have been minimized for that particular choice.

However, there are a large number of disadvantages to this procedure. Even if the minimization of total adverse impacts has been successfully calculated through choice of a particular site, resource misallocation still occurs as a result of the discrepancy between the direct cost to the government and to the generator of the externality (zero cost) as a result of the command decision, and the full social cost which must include all externalities. Consequently, the activity generating the toxic waste receives, in effect, a subsidy with the result that its output tends to be underpriced and over-produced.

In addition to this failure to meet efficiency criteria, the present command and control process creates inequities, as between regions and individuals, by coercive imposition of the externality upon particular individuals in particular regions without the consent of and compensation to those concerned.

Besides the economic cost thus imposed, political costs also emerge from the sequential nature of the go- no-go decision process. If the Federal Government is unable to muster enough political power to make its siting decisions stick and if no alternatives have been proposed, then the process must be started anew with consequent loss of time and accumulation of expenses.

Another disadvantage of the present procedure is failure to consider local preferences for development, versus nondevelopment, conditions of the local economy, size of multiplier effect and related local conditions.

It should be noted that, even under the command and control decision process, some of these disadvantages could be mitigated by the provision of federal aid to the impacted region. In fact, some such limited programs have been initiated under the Coastal Zone Management Act. However, federal assistance has been essentially limited to bridging the gap between the onset of fiscal impacts on local government for providing services and the time when additional revenues would begin to flow to the local government.

It is possible to visualize a much more efficient and equitable system for interregional environmental management based upon financial incentives and local preference. Under this proposed approach, the Federal Government 
would initially list a number of sites for storage of toxic waste or large energy facilities in varied locations. Recognizing the generation of detrimental externalities, it would offer payments to local communities in exchange for siting in each location. The nature of the payments could take many forms but a package should be offered for each site, both to compensate for initial impacts and to meet annual carrying and monitoring costs.

The Federal Government, although it could consider state-proposed sites, should still have final authority over site certification to prevent selection of locations deemed inappropriate because of boundary conditions affecting adjacent states through adverse air or waste flows, ${ }^{2}$ inadequate local knowledge, or other reasons.

In effect, the Federal Government would set up a demand or offer schedule for waste storage or energy sites in order of preference, indicating what it would be willing to pay initially and annually for each location, and taking into account suitability of the site, transportation costs, and monitoring and maintenance costs over the life cycle of the facility. The Federal Government would have an obligation to specify, to the best of its ability, the favorable and unfavorable expected economic and environmental impacts of each site explicitly, citing the possible damages as probability functions.

On the supply side, each local government containing one of the potential sites could review the federal demand options and derive its own supply schedule. The local region would take into consideration its collective elasticity of demand for economic development versus environmental quality, the nature of its local economy and the probable multiplier effect, local damages resulting from construction and operation of the facility, and related matters.

One of the most important aspects of this incentive-based plan would be the guarantee by the Federal Government to compensate individuals and interests already located in the region to be unfavorably impacted. Logically, the cost of compensation and relocation is a part of the supply cost for each site, and could be included in the local government supply schedule provided that local governments could be relied upon to allocate funds for that purpose. However, in order to assure uniform treatment of relocations across regions, federal guarantees would be preferable.

Residents in the area who were concerned about damage from toxic substances either from storage, processing, transportation, or any other adverse externality, would have the option of selling property at fair market prices and receiving relocation assistance. The cost of assisting the exodus of those riskaverse residents could be reduced by permitting the purchasing agent to auction off any property thus acquired to those who had a lower level of personal concern about the dangers involved. Obviously the right of relocation could not be extended to all those near all transportation routes for toxic materials since this would include entire populations of major ports and transport networks. Thus, resource constraints would limit application to those facing high-risk transport hazards. Even if those exposed to significant risk along the 
transportation route were given this right of selling out at appropriate market value, net costs to the society might be minimized since less risk-averse purchasers could potentially cover much of the cost involved. The advantage of such a process is that it would recognize individual preferences and give the market an opportunity to function. Utilizing the market, risk-averse sellers could sell to less risk-averse purchasers, with the government guaranteeing a minimum fair market value. Indeed, profits might even emerge if a net inflow of residents were to result from increased local economic opportunities. In any event, federal underwriting of relocation costs could provide Pareto improvements.

A number of objections can be raised to this scheme. The precise details would have to be worked out with regard to how local governments would decide to offer facilities to meet federal demand curve for sites. Reasonable procedures for voting and decision making would be necessary in those areas where a concensus was difficult to obtain. The Federal Government might have some difficulty in making a clear-cut decision if a large number of regions made supply offers of necessarily non-identical sites.

However, the advantages of such a procedure would be numerous. First of all, the full social cost of siting for an externality-producing facility would be calculated under this procedure and the social costs would then be borne by the Federal Government or, preferably, shifted to the activity which generated them such as the electric energy industry, the nuclear industry, NASA, or even the Department of Defense. Secondly, by specifying both the initial payment and the annual maintenance and monitoring cost, the full life cycle cost for such facilities would be revealed, a type of information which currently is not generated. Transferring these costs back to the generating facility would internalize externalities. If life cycle costing could be combined with the full or mass balance accounting for all of the externalities generated and hazardous materials transport manifest systems, even the emitting activities might receive better protection. ${ }^{3}$

Equity objectives could be served for individuals by assisting risk-averse persons to sell out at protected prices and for local govennments by encouraging the governmental unit to reveal its relative preference for development versus environmental quality in setting its supply schedule for sites. Efficiency objectives could be served as the federal government compared the demand schedule for sites with local government supply schedules and made its choices. If a waste or process were perceived as sufficiently hazardous that no bidder could be obtained at acceptable prices, the question should be raised as to whether its production could be justified in the public interest.

The storage of nuclear waste is only one type of hazardous siting for which the U.S. will need improved decision processes. Large-scale power plants (nuclear and conventional), as well as energy extraction and processing facilities, are becoming so large that the extent of their detrimental externalities is a national problem. Unless economic incentive programs which 
recognize local preferences can be established, we run the risk of growing environmental imperialism by the Federal Government.

Unfortunately, this federal pattern of arbitrary siting of hazardous facilities is also being adopted by states against their own local governmental units, often under pressure from public utilities and other well-organized special interest groups. In Maryland, the Power Plant Siting Act, supported by local utilities, taxes consumers to raise funds for acquiring nuclear power sites with or without the consent of the counties designated for siting. A recent hastily passed hazardous waste siting bill in Maryland appears to have been tailored to benefit a specific chemical manufacturer.

Proposed legislation in New Hampshire would establish a tax on generators of hazardous waste and establish a state "superfund" for cleaning up hazardous waste sites. ${ }^{4}$ The fund could accrue from $\$ 750,000$ to $\$ 1,000,000$ annually from a tax on $1^{1 / 2} \mathfrak{\$} / \mathrm{lb}$. of hazardous waste from industry. ${ }^{5} \mathrm{~A}$ bill in Georgia would vest the State Hazardous Waste Management Authority with the power to condemn land for use as hazardous waste sites. ${ }^{6}$ The Indiana Senate passed a bill permitting the State to override local authorities in siting hazardous waste facilities to strip local growth of any direct power to make siting decisions. ${ }^{7}$

Imaginative use of market incentives instead of these forms of environmental aggression against local communities could avoid some of the polarization emerging between growth advocates and environmental interests.

\section{MARKETABLE POLLUTION PERMITS}

In addition to the siting of hazardous facilities, growing interest in marketable permits for emissions raises another set of issues for interregional equity and efficiency goals, in this case as between the public and private sectors. After decades of advocacy by economists, some states, such as Maryland, and the Federal Government, through EPA programs, are seriously considering the adoption of marketable permits as a device for reducing the cost of pollution control and increasing its efficiency.

One of the leading authorities in this area is Wallace E. Oates, who, in addition to dealing comprehensively with the theory of environmental economics, ${ }^{8}$ has also worked on the operational aspects of marketable emission permits. ${ }^{9}$ Like most economists dealing with this subject, Oates has persuasively identified the efficiency gains to be achieved by such an approach. However, as he and others have recognized, there may often be a conflict between efficiency and equity goals. ${ }^{10}$ The proposal for Maryland, although still not in final form, would confer emission rights on current emitters, calibrated on current emission, entitlements or some past emission rate, to avoid creating an incentive to expand emissions, thereby inflating the magnitude of the saleable rights. Current emitters, after being grandfathered in, would then be entitled either to use or to sell their present emissions rights.

Emitters would have strong economic incentives to reduce emissions; under such a system, any given set of emission or ambient quality objectives could, in 
principle, be achieved at minimum cost. Numerous other efficiency advantages could be listed. The concern here, however, is with the equity and property right implications of initiating such a scheme.

A major problem with this approach is that substantial windfall profits would be conferred upon initial emitters. In effect, those who were the first to pollute would be rewarded, and rewarded in proportion to the magnitude of their pollution, up to permitted levels. The creation of marketable emission rights would be a de facto and de jure transfer of property rights to polluters and a confiscation from the public of any implicit rights to common property environmental resources. The potential capital value of such a wealth transfer is enormous. Additionally, the ethical and moral implications are hardly attractive and may be sufficiently offensive to defeat such a scheme. In fact, the limited evidence available on the potential marketable value of the pollution rights which, in effect, have been appropriated by emitters, indicates that these may be very large indeed. ${ }^{11}$ The value of these emission rights are viewed by marketable permit advocates to be so great, in fact, that attempting to sell these rights to those currently exercising them would be so costly as to jeopardize acceptance of the concept.

Given these two horns of the dilemma, i.e., that pollution rights now being exercised are so valuable those currently enjoying them would strongly resist paying for them and, correspondingly, that these pollution rights are so large that society should not continue giving them away, the problem may be so serious that neither of these polar positions can prevail.

Therefore, if the efficiency advantages of marketable emissions permits are sufficiently great that this innovation should be tried by society (and the potential advantages appear to be sufficiently great to warrant experimentation), then some compromise position on the initial disposition of the rights should be sought. A number of compromises can be visualized. For example, those currently exercising the rights could be asked to make a reasonable payment for them which would then be converted into absolute property rights to be sold thereafter at any time. The initial payment should be made to the public treasury in recognition of the private use of public environmental resources.

Marketable permits could be required to be renewed periodically. Alternatively, the government could auction off these rights periodically, with the proceeds going to the public sector. If the proceeds were assigned to previous holders, they could be made subject to excise or to other forms of taxes.

Excessively frequent reversion of pollution rights to the public would obviously dilute the private property rights in pollution, weaken incentives to find low cost control techniques, and introduce uncertainty for emitters. However, the periodicity of reversion could be negotiated to obtain the desirable efficiency aspects of pollution rights without permanently transferring environmental rights into private control.

In compliance areas, where the full assimilative capacity of the local environment has not been appropriated and federal air and water standards are being met, existing emitters might be permitted property rights to emissions, 
but with any new emitter being required to purchase rights from the public sector. These emitters could also be required to repurchase their emission rights from the public sector, as suggested above, annually or at longer intervals, in order to serve both equity and efficiency objectives.

Requiring periodic renewal of emission rights and payment for such rights to the government can be justified on a number of grounds. First, the government would incur monitoring and other administrative costs to ensure issued emission rights would not exceed a level deteriorating environmental quality below certain standards. Second, the determination of the optimal number of permits would require much costly research on physical and economic damage functions which could be financed from the permit sale proceeds.

As the present author has suggested elsewhere, a federal, state and local hierarchical system could be utilized to provide for interregional efficiency and equity. The federal level should set maximum emission or minimum ambient standards to avoid the deliberate or inadvertant tendency of local regions to site detrimental activities on border locations which cause interregional flows to impact inequitably on downstream regions. ${ }^{12}$

Depending upon local preferences for environmental quality and tradeoffs with regional economic development, state and local governments should be permitted to establish higher environmental quality standards (but not lower than the federally specified standards) by imposing local surcharges on emissions, by issuing fewer permits than the number that would allow ambient quality to fall to the federal level, or by letting local agencies, including private agencies, purchase emissions permits to be set aside without use. ${ }^{13}$ Federal minimum environmental standards are necessary to prevent excessive downstream or downwind externalities, destructive interregional competition and excessive discounting of future environmental damage.

The initial vesting of pollution rights in current emitters would represent a large windfall reward for pollution in proportion to the amount of pollution; this windfall should be shared with the general public.

\section{CONCLUSION}

The U.S. is entering an era in which the Federal Government is beginning to exert a form of environmental imperialism against state governments, which in turn are exercising the same environmental aggression against local governments. This paper makes the point that this approach is both economically inefficient and inequitable in a federal system. Imaginative use of economic incentives and a shared vesting between public and private interests of marketable rights to environmental resources can help to achieve efficient and equitable spatial allocation of economic development and environmental quality within a federal system.

\section{FOOTNOTES}

1 U.S. Department of Energy, "Waste Isolation Pilot Plant, Draft Environmental Impact
Statement," Washington, D.C., Volumes 1 and $2,1979$. 
2 Cumberland, John H., "Interregional Pollution Spillovers and Consistency of Environmental Policy," in Regional Environmental Policy, the Economic Issues, Horst Ziebert, Ingo Walter and Klaus Zimmerman. New York University Press, NY, 1979, pp. 255-281.

3 An example is the Life Science Products disaster in Hopewell, Virginia, where waste from Kepone production was inadequately managed within the plant and surreptitiously discharged into the municipal sewer plant. Had the company been required to file a mass balance statement and account for proper treatment of all waste, rather than going through prosecution and bankruptcy and imposing heavy social costs on the workforce and fishing industry, it might still be in operation, under safer conditions.

4 "New Hampshire State Superfund Bill Passes House, Calls for Siting Aid," Hazardous Waste News, p. 103, (March 30, 1981).

5 "Around the States," Hazardous Waste News, Ibid.

7 "Indiana Senate Passes Controversial Siting Proposal That Calls for State Override," Hazardous Waste News, p. 55, (February 16, 1981).

8 Baumol, William J. and Wallace E. Oates. Theory of Environmental Policy, Englewood Cliffs: Prentice Hall, Inc., 1975.
9 Oates, Wallace E. "The Use of Market Incentives for the Improvement of Air Quality in Maryland," unpublished manuscript, November 1980.

10 For a perceptive treatment of marketable permits, see also Thomas $H$. Tietenberg "Transferable Discharge Permits and the Control of Stationary Source Air Pollution: A Survey and Synthesis," Land Economics, Vol. 56, No. 4, November 1980, pp. 391-416.

11 Palmer, A., et al., Economic Implications of Regulating Chlorofluorocarbons Emissions From Non Aerosol Application, RAND, Chapters 4 and 5, June 1980; Anderson R. J., et al., An Analysis of Alternative Policies for Attaining and Maintaining $A$ Short-term $\mathrm{NO}_{2}$ Standard, MATHTECH: Princeton, Chapters 6 and 7, 1979.

12 Cumberland, John H., "Interregional Pollution Spillovers and Consistency of Environmental Policy," in Regional Environmental Policy, the Economic Issues ed. Horst Ziebert, Ingo Walter and Klaus Zimmerman. New York University Press, NY 1979, pp. 255-281.

13 Cumberland, John $H$. "The Impacts of the Nuclear Power Plant on a Local Community: Problems of an Energy Facility Development," in Energy and the Community, ed. Raymond J. Burby, III and A. Fleming Bell. Ballenger Press: Cambridge, MA, 1978. 